\title{
Consumption of fish and seafood by pregnant Polish women and the supply of docosahexaenoic acid and eicosapentaenoic acid from these products
}

\author{
MAGDALENA BROŚ-KONOPIELKO ${ }^{1, A, B, D-F}$, AGNIESZKA BIAŁEK ${ }^{2, B, D}$, \\ LUIZA OLESZCZUK-MODZELEWSKA ${ }^{1,8}$, BARBARA ZALEŚKIEWICZ ${ }^{1,8}$, \\ ANNA RÓŻAŃSKA-WALĘDZIAK ${ }^{1, \text { B }}$, JUSTYNA TELIGA-CZAJKOWSKA ${ }^{3, \mathrm{E}}$, \\ ANDRZEJ TOKARZ ${ }^{2, B}, \mathrm{D}$, KRZYSZTOF CZAJKOWSKI ${ }^{1, A-D}$
}

${ }^{1}$ The $2^{\text {nd }}$ Department of Obstetrics and Gynecology, Medical University of Warsaw, Poland

2 Department of Bromatology, Medical University of Warsaw, Poland

${ }^{3}$ Department of Obstetrics and Gynecology Didactics, Medical University of Warsaw, Poland

A - Study Design, B - Data Collection, C - Statistical Analysis, D - Data Interpretation, E - Manuscript Preparation, F - Literature Search, G - Funds Collection

Summary Background. Fish and seafood are the main source of docosahexaenoic acid (DHA) and eicosapentaenoic acid (EPA) in the diet. There is no available data concerning the intake of fish and seafood by pregnant Polish women.

Objectives. The purpose of the study was to analyze the consumption of fish and seafood by pregnant women and to estimate the daily supply of DHA and EPA provided by these products.

Material and methods. A fish and seafood intake questionnaire was given to 204 full-term pregnant women.

Results. $23 \%$ of the surveyed women did not eat any fish during pregnancy; $58 \%$ ate fish once a week or once every two weeks; $19 \%$ of pregnant women ate fish 2-3 times a week; only $5 \%$ of respondents ate seafood. The surveyed pregnant women recorded a total of 0.28 (range 0-1.9) g DHA per day and 0.131 (range 0-1.16) g EPA per day from the supply of fish in their diet. The recommended daily requirement varies depending on the source: for DHA $(0.2 \mathrm{~g} /$ day or $0.6 \mathrm{~g} /$ day) and for EPA $(0.22 \mathrm{~g} /$ day); thus, $52 \%$ or even $86 \%$ and $80 \%$ of surveyed women, respectively, obtained through their diet of fish and seafood less than the recommended daily intake of DHA and EPA.

Conclusions. Fish and seafood consumption during pregnancy is either low or rare. The amount of fish and seafood in the diet of pregnant women does not meet the daily requirement for docohexaenic acid and eicosapentaenoic acid. Dietary modifications in pregnancy are strongly advised in order to prevent a deficiency of DHA and EPA.

Key words: fish, pregnancy, diet, eicosapentaenoic acid, seafood, docosahexaenoic acid.

Broś-Konopielko M, Białek A, Oleszczuk-Modzelewska L, Zaleśkiewicz B, Różańska-Walędziak A, Teliga-Czajkowska J, Tokarz A, Czajkowski K. Consumption of fish and seafood by pregnant Polish women and the supply of docosahexaenoic acid and eicosapentaenoic acid from these products. Fam Med Prim Care Rev 2017; 19(3): 191-195, doi: https://doi.org/10.5114/fmpcr.2017.69272.

\section{Background}

Fish and seafood are the main source of docosahexaenoic acid (DHA) and eicosapentaenoic acid (EPA) in the diet. These Omega-3 polyunsaturated fatty acids are essential for normal fetus development, i.e. an increased supply of DHA results in a slightly longer duration of pregnancy, higher birth weight of the infant, reduction of the risk of premature birth and better mental development during the first years of life [1-3]. Mendez et al. evaluated the effect of this diet on child development among the inhabitants of Minorca in Spain [4]. High fish consumption is a characteristic feature of this community. Mendez et al. indicated that the best results were achieved by mothers who ate fish 2-3 times a week [4]. In a randomized double-blind test, the children of pregnant women who were given cod-liver oil (1.2 g DHA and $0.8 \mathrm{~g}$ EPA a day) achieved better results from the Kaufmann's tests during the fourth year of life in comparison with the children of mothers who were given a placebo [2]. In another test conducted among 2.5-year old children of mothers who received fish oil (2.2 g DHA and $1.1 \mathrm{~g}$ EPA a day) during the second half of their pregnancy, better hand-eye coordination was recorded in comparison with the children of mothers who received a placebo [5].
The availability of DHA for the fetus depends on the presence of this acid in a pregnant woman's diet $[6,7]$. There is a preferential transplacental transport of DHA using specific transport proteins [8]. The highest accumulation of this acid by the fetus takes place during the third trimester of pregnancy and during the first years of life [6]. DHA is accumulated mainly in the brain and retina (intrauterine accumulation - total of ca. 67-75 mg PUFA n-3 a day, 43 mg DHA a day) [9]. It is possible to produce DHA from ALA ( $\alpha$-linolenic acid), and this is greater in women than in men; nonetheless, such conversion is insufficient for the requirements of a developing pregnancy [6]. Lack of its adequate supply in a pregnant woman's diet leads to insufficient accumulation of this compound by the fetus and may result in irreversible changes. Insufficient DHA accumulation is also present in prematurely born children, and a supplement of $600 \mathrm{mg} \mathrm{DHA} / \mathrm{d}$ in the last half of gestation resulted in overall greater gestation duration and infant size [10]. For this reason, a basic source of fetal DHA is the docohexaenic acid provided by the mother's diet, and it is recommended that this should be supplied in increased quantities [3]. According to the current recommendations of the Environmental Protection Agency (EPA) and the Food and Drug Administration (FDA), pregnant women ought to eat various types of fatty marine fish at least 2 
or 3 times a week, avoiding the larger predators (shark, swordfish, king mackerel) in order to reduce the risk of methylmercury poisoning [11]. For this reason, the best source of Omega-3 acids is small shoal fish, such as mackerel, sprat and herring [12, 13]. These fish are caught during the first to second year of life, while predators are caught even during the tenth year. Shoal fish have less opportunity to accumulate toxic compounds, which is why they are recommended for pregnant women and children [12]. As a result of the 2004 FDA campaign concerning the negative effects of fish consumption, the fish intake by pregnant women and the entire American society abruptly declined [14]. Research indicates that insufficient consumption of fish ( $<2$ two helpings of fish a week) by pregnant women may affect the future development of their offspring [15].

It is very important to find the correct balance between adequate fish consumption by pregnant women and a simultaneous limitation of methylmercury intake. Cod-liver oil or commercial Omega acid preparations made from cultured algae are an option. However, algae preparations are deprived of other beneficial nutrients found in fish, such as protein, vitamins ( $D$, A), selenium, fluorine and calcium. Among Polish women, fish consumption is low $(15 \mathrm{~g})$ and constitutes only half of the recommended intake ( $30 \mathrm{~g})$ [16]. There is no data concerning the consumption of fish and seafood as the main source of the DHA and EPA by pregnant Polish women.

\section{Objectives}

The purpose of the study was to analyze the consumption of fish and seafood by pregnant women and to estimate the daily supply of DHA and EPA provided by these products, as well as to verify the need of modification to the diet and supplementation of potential deficiencies.

\section{Materials and methods}

A questionnaire was drawn up together with the Bromatology Department of the Pharmacy Faculty and the Laboratory Medicine Division of the Warsaw Medical University, which enabled a detailed assessment of a pregnant woman's diet from the point of view of the consumption of fish and seafood. The questions referred to the frequency (defined as "never", "once every two weeks", "once a week", "2 or 3 times a week", "4-6 times a week", "every day") of consuming the above-mentioned products and their estimated quantity/mass per helping. The size of the helping consumed by the examined women was evaluated with the help of the "Album of photographs of food products and dishes" [17]. The daily intake of Omega acids from fish and other seafood by pregnant women was estimated using the data from tables defining the content of polyunsaturated fatty acids in individual products [18-21]. Although the questionnaire also contained questions concerning the intake of nuts, olive oil and other oils, solid fats, eggs, cereals, fruits and vegetables and information about vitamin supplements, we have focused on and posted the results of the estimation of fish and seafood intake by pregnant women. The patients completed the questionnaire in the presence of researchers. The questionnaire also included information concerning demographic data, general health and the course of pregnancy and labor, as well as the condition and biometric measurements of the newborn. Full-term pregnant women received the questionnaires immediately before going into labor. The Bioethics Commission approved the study design and the written consent of every patient was obtained. The data was analyzed using the Statgraphics Centurion static program. Completed questionnaires were obtained from 204 pregnant women aged $31 \pm 4.5$ years. Most women, $77 \%$, had higher education, only $19 \%$ had secondary education, and $4 \%$ had vocational and elementary education. A correct course of pregnancy was recorded in $63 \%$ of the women, while complications with diabetes during pregnancy appeared in $22 \%$ women; in $17 \%$ of these, gestational diabetes was treated with a diet (GDMG1), and in 5\%, it was treated with insulin (GDMG2, PGDM). In addition, gestational cholestasis appeared in $6 \%$ of the pregnant women, and $4 \%$ were treated for hypertension (PIH). Among the newborns, there were slightly more girls than boys (111 (54.4\%) and 93 (45.6\%), respectively). The mean infant weight was $3471 \pm 443 \mathrm{~g}$, length $-54 \pm 3 \mathrm{~cm}$, and the Ponderal Index was $21.6 \pm 2.6 \mathrm{~kg} / \mathrm{m}^{3}$. The condition of the newborns according to the Apgar scale was determined as good for $96 \%$ in the first minute of life, $98.5 \%$ after the $5^{\text {th }}$ minute of life and $100 \%$ after the $10^{\text {th }}$ minute. A majority of the newborns (88\%) were healthy. Among congenital malformations, there were $10(4.9 \%)$ cases of tied tongue and $6(2.9 \%)$ of VSD. Two boys (0.98\%) had hypospadias, and another two $(0.98 \%)$ had cryptorchidism (Table 1).

\section{Table 1. Characteristic of the participant}

\begin{tabular}{|c|c|c|}
\hline \multicolumn{2}{|l|}{ Characteristics of the participant } & \multirow{2}{*}{\begin{tabular}{|l|}
$n=204$ \\
$31 \pm 4.5$
\end{tabular}} \\
\hline Maternal age (y) & & \\
\hline Maternal race (\%) & white & 100 \\
\hline Maternal ethnicity (\%) & Caucasian & 100 \\
\hline Education (\%) & $\begin{array}{l}\text { higher } \\
\text { secondary } \\
\text { elementary }\end{array}$ & $\begin{array}{c}77 \\
19 \\
4 \\
\end{array}$ \\
\hline Pre-pregnancy BMI $\left(\mathrm{kg} / \mathrm{m}^{2}\right)$ & & $22.7 \pm 3.7$ \\
\hline BMI on enrollment $\left(\mathrm{kg} / \mathrm{m}^{2}\right)$ & & $27.9 \pm 4.1$ \\
\hline Gestation on enrollment (d) & & $272.3 \pm 8.4$ \\
\hline Parity (\%) & $\begin{array}{l}\text { primipara } \\
\text { multipara }\end{array}$ & $\begin{array}{l}46 \\
54\end{array}$ \\
\hline Course of pregnancy (\%) & $\begin{array}{l}\text { uncomplicated } \\
\text { diabetes } \\
\text { (GDMG1/GDMG2/ } \\
\quad \text { /PGDM) } \\
\text { gestational cho- } \\
\text { lestasis } \\
\text { PIH }\end{array}$ & \begin{tabular}{|l|}
64 \\
23 \\
$(18 / 4 / 1)$ \\
7 \\
6
\end{tabular} \\
\hline Smoked during pregnancy (\%) & & 0.5 \\
\hline $\begin{array}{l}\text { Alcohol used during preg- } \\
\text { nancy (\%) }\end{array}$ & & 1 \\
\hline Mode of delivery & $\begin{array}{l}\text { spontaneous birth } \\
\text { cesarean section }\end{array}$ & $\begin{array}{l}69 \\
31\end{array}$ \\
\hline Gender of child (\%) & $\begin{array}{l}\text { male } \\
\text { female }\end{array}$ & $\begin{array}{l}46 \\
54\end{array}$ \\
\hline Newborn's weight (g) & & $3471 \pm 443$ \\
\hline Newborn's body length (cm) & & $54 \pm 3$ \\
\hline $\begin{array}{l}\text { Newborn's Ponderal Index } \\
\left(\mathrm{kg} / \mathrm{m}^{3}\right)\end{array}$ & & $21.6 \pm 2.6$ \\
\hline Developmental disorders & $\begin{array}{l}\text { none } \\
\text { tied tongue } \\
\text { VSD } \\
\text { hypospadias } \\
\text { cryptorchidism }\end{array}$ & \begin{tabular}{|l|}
88.0 \\
4.9 \\
2.9 \\
0.98 \\
0.98
\end{tabular} \\
\hline
\end{tabular}

\section{Statistical analyses section}

The distribution of the data was checked using the Statgraphics Centurion Static Program Version XVII-X64. Data concerning age, maternal BMI and Ponderal Index were distributed normally, and the data was reported as an average value with standard deviation. The results of the daily intake of DHA and EPA from fish and seafood were distributed abnormally, and the data was reported as a median and range. 


\begin{tabular}{|l|l|l|l|l|l|l|}
\hline \multicolumn{2}{|l|}{ Table 2. Frequency of fish consumption by the surveyed pregnant women } \\
\hline Frequency of fish consumption & Not at all & $\begin{array}{l}\text { Once every } \\
\text { 2 weeks }\end{array}$ & $\begin{array}{l}\text { Once } \\
\text { a week }\end{array}$ & $\begin{array}{l}\text { 2-3 times } \\
\text { a week }\end{array}$ & $\begin{array}{l}\text { 4-6 times } \\
\text { a week }\end{array}$ & Every day \\
\hline $\begin{array}{l}\text { Percentage of all pregnant } \\
\text { women }\end{array}$ & 23 & 28 & 11 & 19 & 0 & 0 \\
\hline
\end{tabular}

\begin{tabular}{|c|c|c|c|c|}
\hline $\begin{array}{l}\text { Frequency categories/Fish species } \\
\text { (percentage of pregnant women from the group) }\end{array}$ & $\begin{array}{l}\text { Once } \\
\text { a week (\%) }\end{array}$ & $\begin{array}{l}\text { 2-3 times } \\
\text { a week }(\%)\end{array}$ & $\begin{array}{l}\text { 4-6 times } \\
\text { a week }(\%)\end{array}$ & Every day (\%) \\
\hline Salmon & 30 & 23 & 0 & 0 \\
\hline Tuna & 16 & 10 & 0 & 0 \\
\hline Mackerel & 15 & 21 & 0 & 0 \\
\hline Trout & 5 & 7 & 0 & 0 \\
\hline Cod & 15 & 16 & 0 & 0 \\
\hline Herring & 13 & 14 & 0 & 0 \\
\hline Sardines & 0 & 1 & 0 & 0 \\
\hline Eel & 0 & 0 & 0 & 0 \\
\hline Halibut & 0 & 2 & 0 & 0 \\
\hline Sprat & 3 & 5 & 0 & 0 \\
\hline Pollock & 3 & 1 & 0 & 0 \\
\hline
\end{tabular}

\section{Results}

\section{Fish consumption}

\section{General fish consumption by pregnant women}

$23 \%$ of the surveyed women did not eat fish at all during pregnancy. $58 \%$ of women ate fish once a week or once every two weeks. $19 \%$ of surveyed women ate fish 2 or 3 times a week. None of the surveyed women consumed fish more often than 4 times a week (Table 2).

The most popular fish species eaten by the surveyed pregnant women was salmon. Among the pregnant women from the group "once a week frequency" vs "2-3 times a week frequency", $30 \%$ vs $23 \%$ of them, respectively, declared eating salmon (Table 3).

\section{Daily intake of DHA supplied by fish in the diet of pregnant} women

The daily intake of DHA from fish by pregnant women was estimated. The surveyed pregnant women were supplied with 0.28 (range 0-1.9) g DHA per day in their diet. 23\% of the surveyed women did not obtain DHA at all from fish. In $29 \%$ of the cases, the supply was less than $0.2 \mathrm{~g}$ DHA a day, and in $13 \%$, it equaled $0.2 \mathrm{~g} \mathrm{DHA}$ per day. Only $14 \%$ of women were provided $0.3 \mathrm{~g}$ DHA per day with fish, $5 \%-0.4 \mathrm{~g}$ DHA, $2 \%-0.5 \mathrm{~g}$ DHA, $3 \%-0.6 \mathrm{~g}$ DHA, $1 \%-0.7 \mathrm{~g}$ DHA and $1 \%-0.8 \mathrm{~g}$ DHA. $0.9 \mathrm{~g}$ DHA per day provided with fish $2 \%$ of surveyed women and more than $1 \mathrm{~g}$ per day - 7\% of pregnant women. The maximum consumption of DHA derived from fish - consumed by $0.5 \%$ of pregnant women - was $1.9 \mathrm{~g}$ DHA per day. $52 \%$ of pregnant women did not fulfill the recommended minimal daily intake requirement for DHA $(0.2$ $\mathrm{g} /$ day) obtained from fish. According to the Recommendations of the Polish Gynecology Society, $86 \%$ of the surveyed women didn't meet the daily requirement for DHA $(0.6 \mathrm{~g} /$ day).

Daily intake of EPA supplied by fish in the diet of pregnant women

The daily intake of EPA from fish by pregnant women was estimated. The surveyed pregnant women were supplied with 0.131 (range $0-1.16$ ) g EPA a day. $80 \%$ of the surveyed pregnant women did not fulfill the recommended minimal daily intake re- quirement for EPA (0.22 g EPA/day) obtained from fish. $23 \%$ of them did not obtain EPA from fish at all during pregnancy. EPA provided with fish in the amount of $0.22 \mathrm{~g}$ or more per day was reported by $19 \%$ of the surveyed women, and more than $1.16 \mathrm{~g}$ EPA per day was reported only by $1 \%$.

\section{Seafood}

\section{General seafood consumption by pregnant women}

$95 \%$ of the responders did not eat seafood at all. Only $4.5 \%$ of all the polled women declared that they had been eating shrimp once in two weeks, while only $0.5 \%$ reported eating squid equally frequently during pregnancy. None of the polled women declared consuming oysters, lobsters, clams or other mussels.

\section{Daily intake of DHA and EPA supplied by seafood in the diet of pregnant women}

The surveyed pregnant women were supplied with 0.0005 (range 0-0.03) g DHA and 0.0006 (0-0.02) g EPA per day from seafood.

\section{Discussion}

The basic products in a diet that supplies DHA and EPA are fatty marine fish, seafood and algae [19]. The intake of these products by the analyzed pregnant women was low. About $1 / 4(23 \%)$ of the surveyed patients did not eat fish at all during pregnancy. Only $19 \%$ of the pregnant women ate fish $2-3$ times a week, as recommended by the FDA. The most popular fish eaten by the surveyed women was salmon. According to Koletzko et al., weekly consumption of two helpings of fish, i.e. salmon and mackerel or mackerel and herring, fulfill the DHA requirement for pregnant women [22]. The surveyed pregnant women consumed seafood and algae sporadically, unlike the women of Minorca, where seafood was the staple diet of future mothers [4].

Low fish consumption by pregnant women is not a unique problem for the Polish population. The Environmental Protection Agency and the Food and Drug Administration conducted studies that assessed fish consumption by pregnant American 
women. An FDA analysis of fish consumption data found that $50 \%$ of surveyed pregnant women ate fewer than 2 ounces a week, far less than the amount recommended [23]. Low fish intake by pregnant Polish women may be explained by habitual tendencies, as fish consumption in Poland is low. In her studies of food product consumption among the adult Polish population, Sygnowska et al. demonstrated that fish intake among women, as well as men, was significantly lower than recommended. It amounted to $15 \mathrm{~g}$ a day and $16 \mathrm{~g}$ a day, respectively, instead of the recommended $30 \mathrm{~g}$ a day and $35 \mathrm{~g}$ a day, respectively [16]. On the other hand, in North American countries, low fish consumption may be due to an increased fear of methylmercury contamination. The 2004 FDA recommendation for pregnant women and small children limited fish intake to only 1-2 helpings a week. Consequently, the fish intake in both these groups declined dramatically. After a great deal of criticism, stating that as a result of this recommendation, pregnant women and children are deprived of valuable nutrients, there followed a revaluation of the advantages and disadvantages of fish consumption. As a result, in 2017, the FDA released a new recommendation that fish with a relatively low level of contamination should be eaten 2-3 times a week [23].

Nochera et al. demonstrated that the low intake of products containing DHA and EPA acids may also depend on an economic factor [24]. Most of the women we studied had higher education and a similar economic status.

Data provided in the "Tables of contents and nutrition value of food products" indicates that DHA is present in the greatest quantities in marine fish and algae [19]. Among its sources are fresh salmon $(2.1 \mathrm{~g} / 100 \mathrm{~g}$ of the edible part of the product), fresh mackerel $(1.12 \mathrm{~g} / 100 \mathrm{~g})$, salted herring $(0.89 \mathrm{~g} / 100$ $\mathrm{g})$, fresh tuna $(0.68 \mathrm{~g} / 100 \mathrm{~g})$, halibut $(0.37 \mathrm{~g} / 100 \mathrm{~g})$, cod $(0.12$ $\mathrm{g} / 100 \mathrm{~g})$ and sardines $(0.1 \mathrm{~g} / 100 \mathrm{~g})$. It is recommended that pregnant and lactating women should aim to achieve an average dietary intake of at least $0.2 \mathrm{~g}$ DHA a day [22]. 52\% of the studied women were supplied with less than $0.2 \mathrm{~g}$ DHA per day by fish. According to the Recommendations of the Polish Gynecology Society, pregnant women who consume small quantities of fish ought to be supplied with $0.6 \mathrm{~g}$ of DHA per day in their diet, starting from the onset of pregnancy [25]. Keeping this recommendation in mind, $86 \%$ of the surveyed women were not provided the right amount of DHA from fish in their diet. In complicated pregnancies threatened by premature delivery, supplementation ought to be even greater, amounting to $1 \mathrm{~g}$
DHA a day [25]. In our study group, there were no pregnancies threatened with premature delivery.

The most important source of eicosapentaenoic acid is fish, i.e. salted herring $(0.96 \mathrm{~g} / 100 \mathrm{~g}$ of the edible parts of the product), sardines $(0.90 \mathrm{~g} / 100 \mathrm{~g})$, fresh salmon $(0.71 \mathrm{~g} / 100 \mathrm{~g})$, fresh mackerel $(0.63 \mathrm{~g} / 100 \mathrm{~g})$, fresh tuna $(0.32 \mathrm{~g} / 100 \mathrm{~g})$, halibut $(0.14$ $\mathrm{g} / 100 \mathrm{~g})$ and cod $(0.06 \mathrm{~g} / 100 \mathrm{~g})$ [19]. The EPA requirement was defined in combination with DHA. According to the recommendations of the Polish Pediatric Society for pregnant women and small children, the daily requirement is 1-1.5 g [26]. According to EFSA, the combined daily requirement for EPA + DHA for pregnant women is $0.45 \mathrm{~g}$ [27]. The studied pregnant women were supplied with only $0.13 \mathrm{~g}$ EPA a day.

Because polyunsaturated fatty acids (DHA, EPA) are essential elements of a pregnant woman's diet from the point of view of correct fetal development, it is important to determine the intake of fish and seafood as the main source of DHA and EPA among pregnant women in order to plan proper care for them. In this paper, we have focused on and posted the results of the estimation of fish intake by pregnant women, which was a part of an overall work on the intake of all Omega acids by pregnant women. We believe that the separate presentation of results on the consumption of fish and seafood by pregnant Polish women deserves a separate publication. It is important to emphasize the fact that the intake of fish and seafood by pregnant women is low. As a stand-alone product, they do not provide the correct supply of DHA and EPA in accordance with established standards for pregnant women. To prevent shortages, pregnant women should be aware that they should change their diet and eating habits. Pregnant women ought to eat various types of fatty marine fish at least 2 or 3 times a week, avoiding the larger predators in order to reduce the risk of methylmercury poisoning. It should be remembered that there is a possibility of supplementation in the absence of adequate supply [28].

\section{Conclusions}

1. The consumption of fish during pregnancy is low. Seafood consumption among the surveyed pregnant Polish women was sporadic.

2. The consumption of fish and seafood by the pregnant Polish women, as the only source of DHA and EPA fatty acids, is insufficient to meet dietary needs. This requires changes in the diet.

Source of funding: This work was funded by the authors' resources. Conflict of interest: The authors declare no conflict of interests.

\section{References}

1. Makrides M, Gibson RA, McPhee AJ, et al. Effect of DHA supplementation during pregnancy on maternal depression and neurodevelopment of young children: a randomized controlled trial. JAMA 2010; 304(15): 1675-1683.

2. Helland IB, Smith L, Saarem K, et al. Maternal supplementation with very-long-chain $n-3$ fatty acids during pregnancy and lactation augments children's IQ at 4 years of age. Pediatrics 2003; 111(1): 39-44.

3. Cetin I, Alvino G, Cardellicchio M. Long chain fatty acids and dietary fats in fetal nutrition. J Physiol 2009; 587: 3441-3451.

4. Mendez MA, Torrent M, Julvez J, et al. Maternal fish and other seafood intakes during pregnancy and child neurodevelopment at age 4 years. Public Health Nutr 2009; 12(10): 1702-1710.

5. Dunstan JA, Simmer K, Dixon G, et al. Cognitive assessment of children at age 2(1/2) years after maternal fish oil supplementation in pregnancy: a randomized controlled trial. Arch Dis Child Fetal Neonatal Ed 2008; 93(1): 45-50.

6. Gil-Sanchez A, Demmelmair H, Parrilla JJ, et al. Mechanisms involved in the selective transfer of long chain polyunsaturated fatty acids to the fetus. Front Genet 2011; 2: 57.

7. Lauritzen L, Carlson SE. Maternal fatty acid status during pregnancy and lactation and relation to newborn and infant status. Matern Child Nutr 2011; 7(Suppl. 2): 41-58.

8. Innis SM. Dietary (n-3) fatty acids and brain development. J Nutr 2007; 137(4): 855-859.

9. Rogers LK, Valentine ChJ, Keim SA. DHA supplementation: current implications in pregnancy and childhood. Pharmacol Res 2013; 70(1): 13-19.

10. Carlson SE, Colombo J, Gajewski BJ, et al. DHA supplementation and pregnancy outcomes. Am J Clin Nutr 2013; 97(4): 808-815.

11. Environmental Protection Agency and Food and Drug Administration. Fish: what pregnant women and parents should know [cited 20.04.2017]. Available from URL: https://www.fda.gov/food/foodborneillnesscontaminants/metals/ucm393070.htm. 
12. Oken E, Wright RO, Kleinman KP, et al. Maternal fish consumption, hair mercury, and infant cognition in a U.S. cohort. Environ Health Perspect 2005; 113(10): 1376-1380.

13. Sagiv SK, Thurston SW, Bellinger DC, et al. Prenatal exposure to mercury and fish consumption during pregnancy and attention-deficit/ /hyperactivity disorder-related behavior in children. Arch Pediatr Adolesc Med 2012; 166(12): 1123-1131.

14. Environmental Protection Agency and Food and Drug Administration [2004]. What you need to know about mercury in fish and shellfish [cited 06.07.2015]. Available from URL: www.fda.gov/food/foodborneillnesscontaminants/metals/ucm351781.htm.

15. Koletzko B, Lien E, Agostoni C, et al. The roles of long-chain polyunsaturated fatty acids in pregnancy, lactation and infancy: review of current knowledge and consensus recommendations. J Perinat Med 2008; 36(1): 5-14.

16. Sygnowska E, Waśkiewicz A, Głuszek J, et al. Spożycie produktów spożywczych przez dorosłą populację Polski. Wyniki programu WOBASZ. Kardiol Pol 2005; 63(Supl. 4): 670-676 (in Polish).

17. Szponar L, Wolnicka K, Rychlik E. Album fotografii produktów i potraw. Warszawa: Instytut Żywności i Żywienia; 2000 (in Polish).

18. Gladyshev MI, Sushchik NN, Makhutova ON, et al. Content of essential polyunsaturated fatty acids in three canned fish species. Int J Food Sci Nutr 2009; 60(3): 224-230.

19. Kuchnatowicz H, Nadolna I, Przygoda B, et al. Tabele składu i wartości odżywczej żywności. Warszawa: Wydawnictwo Lekarskie PZWL; 2005 (in Polish).

20. Li G, Sinclair AJ, Li D. Comparison of lipid content and fatty acid composition in the edible meat of wild and cultured freshwater and marine fish and shrimps from China. J Agric Food Chem 2011; 59(5): 1871-1881.

21. Stołyhwo A, Kołodziejska I, Sikorski Z. Long chain polyunsaturated fatty acids in smoked Atlantic mackerel and Baltic sprats. Food Chemistry 2006; 94: 589-595.

22. Koletzko B, Cetin I, Brenna JT, et al. Dietary fat intakes for pregnant and lactating women. Br J Nutr 2007; 98: 873-877, doi: 10.1017/ /S0007114507764747.

23. Environmental Protection Agency and Food and Drug Administration. FDA and EPA issue final fish consumption advice [cited 05.07.2017]. Available from URL: https://www.fda.gov/newsevents/newsroom/pressannouncements/ucm537362.htm

24. Nochera CL, Goossen LH, Brutus AR, et al. Consumption of DHA + EPA by low-income women during pregnancy and lactation. Nutr Clin Pract 2011; 26(4): 445-450.

25. Dębski R, Karowicz-Bilińska A, Oszukowski P, et al. Rekomendacje Polskiego Towarzystwa Ginekologicznego dotyczące stosowania suplementacji kwasem dokozaheksaenowym w profilaktyce porodu przedwczesnego. Ginekol Pol 2014; 85(4): 318-320 (in Polish).

26. Stanowisko Ekspertów Polskiego Towarzystwa Pediatrycznego (PTP) i Polskiego Towarzystwa Badań nad Miażdżycą (PTBnM) dotyczące przeciwdziałaniu stanom niedoborowym wielonienasyconych kwasów tłuszczowych omega-3 w żywieniu kobiet w ciąży, niemowląt i dzieci w Polsce. Czyn Ryz 2007; 1: 3-4 (in Polish).

27. Rozporządzenie Komisji Europejskiej (UE) nr 440/2011 z dnia 6 maja 2011. Dziennik Urzędowy Unii Europejskiej L 119/4; 2011 [cited 04.07.2017]. Available from URL: http://gis.gov.pl/images/bz/prawo/2011-440_pl_oświadcz.pdf (in Polish).

28. Rekomendacje Grupy Ekspertów dotyczące spożycia i suplementacji diety kwasami omega-3 w populacji ludzi dorosłych. Fam Med Prim Care Rev 2007; 9(1): 175-177 (in Polish).

Tables: 3

Figures: 0

References: 28

Received: 29.04.2017

Revised: 28.05.2017

Accepted: 07.07.2017

Address for correspondence:

Magdalena Broś-Konopielko, MD, PhD

II Katedra i Klinika Położnictwa i Ginekologii WUM

ul. Karowa 2

00-315 Warszawa

Polska

Tel.: +48 22 596-64-21

E-mail: brosmagda@wp.pl 